\title{
THE REPOSSESSION OF A COMPLEX LANGUAGE: THE CASE OF THE FRENCH LANGUAGE IN CAMEROON
}

\section{Charles Esambe Alobwede ${ }^{*} \mathbb{\Xi}$}

${ }^{1}$ Department of English, University of Yaounde 1, Cameroon

DOI: https://doi.org/10.29121/granthaalayah.v8.i5.2020.134

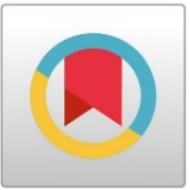

Article Type: Case Study

Article Citation: Charles

Esambe Alobwede. (2020). THE

REPOSSESSION OF A COMPLEX

LANGUAGE: THE CASE OF THE

FRENCH LANGUAGE IN

CAMEROON. International

Journal of Research -

GRANTHAALAYAH, 8(5), 208-

220.

https://doi.org/10.29121/grant

haalayah.v8.i5.2020.134

Received Date: 18 May 2020

Accepted Date: 31 May 2020

Keywords:

Repossession

Imposition

Colonisation

Language Variety

Appropriation

Camfranglais

Complex Language

\section{ABSTRACT}

This article sets out to study the evolution of the French language in Cameroon from the period of colonisation to the present. The article focuses in particular on the use of the language during the colonial period and its imposition on Cameroonians through the French policy of assimilation. Contrary to the British policy of indirect rule, France considered its colonies as oversea territories (la France outre-mer) whichss had to speak and write the French language in a manner as prescribed by the Académie Française. Our investigation looks at the evolution of the language after independence and the different varieties that developed from mainstream French: these include Cameroon popular French (CPF) or the social variety, and a hybrid variety (camfranglais) used mostly by the younger generation of Cameroonians. We aim at evaluating the influence of the latter variety, in order to analyse the radical transformation process that the French language is experiencing in French Africa in general and in Cameroon in particular. The article aims at validating our hypothesis that the French language as used in Cameroon is a repossession of a very complex language.

\section{INTRODUCTION}

"Ma Patrie, c'est la langue que j'écris" (Antoine Rivarol : 1784, qtd. in Le français hors de France). My homeland is the language I write.

The use of a language in every sociolinguistic environment is peculiar to every country. Cameroon is situated in the CEMAC $^{1}$ zone in Central Africa and partly in West Africa, bordering the Bight of Biafra in Nigeria. The country is sometimes referred to as "Africa in miniature" because it exhibits all the major climates and vegetation of the African

\footnotetext{
${ }^{1}$ Central African Economic and Monetary Community
}

(C) 2020 The Author(s). This is an open access article distributed under the terms of the Creative Commons Attribution License, which permits unrestricted use, distribution, and reproduction in any medium, provided the original author and source are credited. 
continent: mountains, desert, rain forest, savannah, grassland, and ocean coastland, as well as three of the four major language groups in the continent. The country has 279 home languages (Ethnologue, 2005) shared by a population of almost twenty million inhabitants. There are two official languages: French and English, and other lingua franca used for interaction among the citizens. The French language has a wider use than any other language giving that four-fifth of the country is officially French-speaking and one-fifth, English-speaking. Literacy in French for individuals of age 12 and above, rose from $41.3 \%$ to $57.6 \%$ between 1987 and 2005 while that of English rose from $13.4 \%$ to $25.3 \%$ within the same period. The global proportion of individuals literate in official languages markedly increased between 1987 and 2015.

A study carried out in 2005 shows that, the probability to be literate in French while being Anglophone is $0.46 \%$ while that of being literate in English while being Francophone is $0.20 \%$, resulting from the predominant status of the French language in the country as a whole. The tendency has persisted especially with the present highly urban exodus as a result of the "Anglophone" crisis which started in November 2016.

Table 1: Literacy in official languages according to the 2005 census (Population of age 12 and above)

\begin{tabular}{|l|c|c|}
\hline Language & Population & Percentage (\%) \\
\hline French (total) & 6.405 .981 & 57.6 \\
\hline English (total) & 2.802 .794 & 25.2 \\
\hline French only & 5.112 .479 & 46.0 \\
\hline English only & 1.509 .292 & 13.6 \\
\hline French and English & 1.293 .503 & 11.6 \\
\hline Neither French nor English & 3.199 .221 & 28.8 \\
\hline Total & 11.114 .495 & 100.00 \\
\hline
\end{tabular}

Source: https://en.wikipedia.org/wiki/Languages_of_Cameroon

Table 2: Literacy in official languages according to the 2005 census (Population of age 15 and above)

\begin{tabular}{|l|c|c|}
\hline Language & Population & Percentage (\%) \\
\hline French (total) & 5.566 .339 & 57 \\
\hline English (total) & 2.448 .914 & 25 \\
\hline French only & 4.401 .333 & 45 \\
\hline English only & 1.283 .908 & 13 \\
\hline French and English & 1.165 .006 & 12 \\
\hline Neither French nor English & 2.909 .664 & 30 \\
\hline Total & 9.845 .479 & 100.00 \\
\hline
\end{tabular}

Source: https://en.wikipedia.org/wiki/Languages_of_Cameroon

The French language thus plays the role of an official language, of a second language, of a foreign language and of a mother-tongue (for a minute number of Cameroonian children). It is used in the administration, in churches, in the court rooms, in daily interaction, in schools, etc. (Wamba and Noumssi 2006; Biloa 2003; Onguene Essono 1996).

Giving the bilingual nature of the country, the linguistic environment imposes on the user of the French language, a number of constraints. The switch from an L1 French situation to an L2 situation is not as smooth as one can think, for the speaker has a mass of information, not only from his/her L1, but equally from all the other languages he/she is confronted with in his/her plural-linguistic environment.

The French language was introduced in Cameroon after the First World War with the defeat of Germany by the combined Allied forces. In 1919, the League of Nations partitioned Cameroon between the French (4/5 of the territory) and the British (1/5 of the territory). Today, the particular practice of the French language in the country has enabled it to be both a common language and a vernacular language. There are various factors which explain this. Historically, the process of the expansion of the French language was done through schools which trained skilled persons whose task consisted in exploiting agricultural and natural resources on behalf of the colonial companies. From a political and ideological view point, the French language, for the colonisers, was the instrument used to bring civilisation to the colonised who were thought or misunderstood to be backwards. Under these conditions, the home languages were and continue to be relegated to a lower level. Like the colonial authorities, the leaders of independent 
Cameroon have continued to perpetuate the linguistic policy favourable to Western languages (French and English) for the reinforcement of national unity and the enhancement of cordial relationship with other countries.

The French language, as practiced in Cameroon today, is the result of a long process. Many factors have contributed to shape the face of the language and have had effects on the perception of francophone Cameroonians. Apart from the factor earlier mentioned, other factors are linked to the implantation of the language in French colonies and the quality of the language to which indigenes were exposed. The choice of the variety or varieties of the language imposed by the French in its colonies was not short of political or even ideological ulterior motives. During the colonial period, a number of pedagogic practices nourished the existing colonial ideology.

The present article outlines the historical background to the study and the conditions on which the French language was implanted in Cameroon. The article will analyse the evolution of the language after independence, a period during which other factors such as the multiplicity of the languages spoken, democratisation and the rapid development of schools, with as consequence, massive school failures at every level of the system, favoured the constitution of various distinct varieties of the language in Cameroon within a multilingual setup.

\section{HISTORICAL BACKGROUND}

As earlier said, the French language was introduced in Cameroon after the First World War which saw the defeat of Germany in 1918 by the combined Allied forces. Before this date, Germany had annexed the country in 1884 and imposed the German language which was used side-by-side with the home languages. The coming of French and English after the war saw a turning point in the linguistic landscape of the country. After the Versailles Peace Treaty in 1919, Cameroon was handed as a mandated territory to France and Britain for governance. While Britain adopted indirect rule to govern its section of the country, the French applied the policy of assimilation as was the case in all other French colonies in Africa.

In the domain of education, the major orientation given by the French to schools in Cameroon aimed at producing utilitarian Cameroonians. Hardy cited by S.P. Ekanza (1972, p. 163) writes, "Nos écoles professionnelles s'attachent avant tout à former des dessinateurs, des mécaniciens, des ouvriers à fer (forgerons, ajusteurs), des chaudronniers." A similar idea is expounded by Albert Tévodjré cited by Ekanza (ibid) in the following terms, "l'enseignement sera développé aux colonies dans la mesure où il servira les intérêts coloniaux." Thus, schools were needed to train auxiliaries of the administration, interpreters, and traders to run the state of affairs.

The need for auxiliaries, capable of assisting the colonial authority to put in place its politico-economic expansionist programme determined the choice of the academic content. The French language was to be the priority language in the teaching of the content. During this period, teaching was essentially related to practical economy. The major concern of the colonialists was systematic exploitation of human and agricultural resources without any investment. Such preoccupation was reflected at three levels in structuring the academic content; the 'village school', the 'regional school', and the 'urban school'.

'Village schools' were not tailored to issue academic certificates. Everything theoretical was forbidden, and only what was for immediate consumption was recommended. The school did not aim at training an elite, but auxiliary subalterns, interpreters, cooks, etc. 'Regional schools', on the other hand, were found at the headquarters of circles. Pupils who attended such schools were among the best from the 'village schools'. They were taught agriculture and manual labour. At the end of the $4^{\text {th }}$ year, students graduated with certificates in agriculture, woodwork, bricklaying, tailoring, etc. 'Urban schools' were found in the capital city (Yaoundé). These were reserved for European children and a few children of similar status: children of chiefs and those of civil servants. The syllabus for 'urban schools' was that of Metropolitan France. At the end of the $6^{\text {th }}$ year, the students were awarded the Certificat d'Etudes Primaires ${ }^{2}$.

While the 'village schools' and the 'regional schools' were training pupils for manual and rural labour, the 'urban schools' prepared the pupils for trade and as state employees for the colonial administration. The fundamental question here is to know in what language content was taught.

\section{THE FRENCH CONCEPT OF A SUPERIOR LANGUAGE}

2 The equivalence of the First School Leaving Certificate in the English educational sub-system. 
"Tout français, ou presque, se sent ou se croit grammarien de droit divin". This tongue-in-check remark by the French linguist, Pierre Alexandre (1967) contains more than a grain of truth. Indeed, he goes on to note that: "La France est, autant que je sache, le seul pays au monde où la plupart des journaux populaires possèdent une chronique grammaticale" (ibid: 35). More alarming is the declaration by Sorbonne Professor, René Etiemble: "The French language is a treasure. To violate it is a crime. Persons were shot during the war for treason. They should be punished for degrading the language" (qtd. in Lockwood, 1973)

In 1539, François I signed an ordinance at Villers-Cotterêts imposing the use of French in all official documents. This historic event not only signalled one of the first French acts of liberation from Latin, but also marked the beginning of a policy suppressing other languages spoken throughout France in the affirmation of centralised power.

The $16^{\text {th }}$ century also saw the publication of DuBellay's celebrated Défense et illustration de la langue française (1549), a manifesto of the Plëiade group affirming the excellence of French as a literary language. But it is in the $17^{\text {th }}$ century, with the writings of the poet, Malherbe and the grammarian, Vaugelas and the founding of the Academie Française by Richelieu (an institution that has survived into the $21^{\text {st }}$ century) that the purification and reform of the French language began in earnest. The claim of the superiority of French, owing to its crystal clarity and rigour which dates from this period, as well as a vigorous defence of it from outside impurities, has continued even to this day as the above quotation from René Etiemble attests.

The position given the language by the French, reflects a long-standing and deep-seated conviction that their language is intimately tied to their identity and grandeur as a nation and as a civilisation. In an article published in New York Times, a former French Prime Minister, Edouard Balladur, asserts that defending the French tongue is, "an act of faith in the future of our country" and his minister of Culture, Jacques Toubou, would later declare in support of the law that, for the French, their language, "is their primary capital, the symbol of the dignity, the passageway to integration, the diapason of a universal culture, a common heritage, part of the French dream" (qtd. in Riding). Indeed, the French see their language as a supreme civilizing force and, giving the belief in the superiority of theirs, over the centuries the French have deemed it their sacred mission to bring its benefits to those 'unfortunate enough' not to speak the language.

Fredric Michelman (1995) concludes in one of his writings that, if 'inferior' languages do exist, however, in keeping with the egalitarian ideals of the French Revolution, there are no intrinsically inferior peoples, only those who are at a lower level of development. Western humanistic values, best embodied in French culture and language, the argument runs, are therefore 'universal' and are accessible to all. Thus, the $18^{\text {th }}$ century writer, Rivarol could assert: "sure, sociable, reasonable, it is no longer only the French language, it is the human language" (qtd in Gordon); and $20^{\text {th }}$ century philosopher, Etienne Gilson could write: "Notre particularité, c'est notre universalité" (qtd in Betts). Many critics have characterised this so-called 'universality' as blatant ethnocentrism (Gordon, ibid), and it is clear that this principle justified, for the French, the 'civilising mission' carried out in Africa and elsewhere in the French Empire.

\section{FRENCH LANGUAGE POLICY IN CAMEROON: 1918 TO THE BRAZZAVILLE CONFERENCE}

French linguistic policy in the colonies in general and in Cameroon in particular was in line with colonialist ideology. Colonisation was considered an integral part of the French 'civilisation' and 'humanitarian' mission; a doctrine which the French Resident General in Morocco summarised thus:

La colonisation, telle que nous l'avons toujours comprise n'est que la haute expression de la civilisation. À des peuples arriérés ou demeurés à l'écart des évolutions modernes, ignorant parfois les formes du bien-être le plus élémentaire, nous apportons le progrès, l'hygiène, la culture morale et intellectuelle, nous les aidons à s'élever sur l'échelle de l'humanité. Cette mission civilisatrice, nous l'avons toujours remplie à l'avant-garde de toutes les nations et elle est un de nos plus beaux titres de gloire. (Cited in Boutin, 2002, p. 29).

The vector of this civilisation mission was nothing else but the French language. Teach the colonised people the French language, and with that, learning the French culture will be seen as a patriotic duty and as a moral obligation. The French linguist, Pierre Alexandre, in a sardonic verve, sums up the French colonial policy in education and administration:

La politique coloniale française en matière d'éducation et d'administration est facile à définir ; c'est celle de François $1^{\mathrm{e}}$, de Richelieu, de Robespierre et de Jules Ferry. Une seule langue est enseignée dans les écoles, admise dans les tribunaux, utilisée dans l'administration : le français, tel que défini par les avis de l'Académie et les décrets 
du ministre de l'Instruction Publique. Toutes les autres langues ne sont que folklore, tutu panpan, obscurantisme, biniou et bourrée, et ferments de désintégration de la République. (111-112).

These ideological principles, already experimented in France, will show their limits in the colonies and especially in Cameroon with the existence of a plethora of languages. The general multilingual situation, the absence of qualified staff and especially the structuring of the school system into 'village schools', 'regional schools', and 'urban schools' created a situation where teaching in the indigenous languages could not have been forbidden completely. A circular note dated 5 January 1939 stipulated that, in line with a letter signed by Colonies, "l'usage des langues indigènes... est autorisé à titre complémentaire pour l'enseignement pratique et pour l'éducation professionnelle ou ménagère" (extract of circular note quoted by Queffelec, 1955). In application of the circular note, a number of textbooks were written in some home languages. This experience was short-lived and the multitude of idiomatic expressions in the home languages was raised as a reason to definitely impose the French language as the only language of education, giving that even in France, the same argument was raised to drop the use of 'patois' as wanted by Father Grégoire, when during the convention of $20^{\text {th }}$ July 1793 he declared:

Il faut qu'on examine la nécessité et les moyens d'anéantir les patois et d'universaliser l'usage de la langue française, car dans l'étendue de toute la nation, tant de jargons sont autant de barrières qui gênent les mouvements du commerce.

The linguistic phenomenon that marked the situation of the French language in Cameroon was the coming of the French infantry (le français tirailleur) during a time when there was hesitation in the choice of language for education. What was known as 'le français tirailleur' or 'français pidginisé' was a variety that existed in all French colonies in Africa. It was born out of the first contacts between the colonisers and the local populations in three different situations: at job sites, in the army, and in schools. At job sites and building sites, some non-indigenes known as 'les petits blancs' or 'les petits colons', relatively more in number than those of the high colonial society, were in permanent contact with other Africans of diverse ethnic and linguistic origins. A variety of simple and rudimentary French developed among this group of persons. This variety was known as 'petit-nègre' because, according to the ideology of the time, the variety was adapted to Black mentality. This is what Delafosse (1904), quoted in Boutin (2002) says of the variety:

Les indigènes ont beau parler notre langue, nous avons toujours beaucoup de mal à nous faire comprendre et à les comprendre, et comme il n'est pas naturel, puisque nous nous estimons supérieurs à eux, que ce soit eux qui se mettent dans notre peau, c'est à nous de nous mettre dans la leur [...] il faut évidemment n'employer que les formes les plus simple des mots, mais surtout il faut n'employer que les mots que les Noirs peuvent comprendre.

According to Delafosse (ibid), the difficulties in communication between Blacks and Whites gave birth to this type of interlingua expression, although he thinks that it was of Black making, because speaking standard French to the Blacks would have been a waste of time. Delafosse (ibid):

Que c'est nous qui avons inventé le 'petit nègre' et que si nous parlions aux Noirs un français correct, ils parleraient de même. Ce raisonnement est puéril ; si nous ne voulons parler à un Noir qu'un français correct, il sera plus d'un an avant de pouvoir nous comprendre et quand il nous comprendra enfin, il nous répondra en petit-nègre : voilà la vérité (je ne parle pas bien entendu d'un Noir auquel on apprendrait le français de façon régulière).

The variety of the language talked of here, was that used by the famous 'tirailleurs camerounais' who learned it during their military training. It was equally used by all French African soldiers during the two world wars. The variety played an important role in the spreading of the French language in most parts of Cameroon. It should be noted that this variety of the French language was used in schools at the beginning of the colonisation process. Some former ex-service men were recruited as teachers in the 'village schools'. Ambroise Queffelec (1995) in citing Amayé (1984) points out that:

Le personnel enseignant dans [les] écoles officielles était constitués par des moniteurs improvisés provenant soit du commerce défaillant des compagnies concessionnaires, soit du service de l'armée [...]. C'est dans ces écoles qu'on comptait essentiellement les gens parlant le français 'petit-nègre' (le moi y'en a dit).

Some examples to illustrate this variety include:

1) Son la maison (sa maison)

2) Ça y en a mon la route (c'est ma route)

3) Moi y en a maladie (je suis malade)

4) Moi y'a pati (je suis parti)

5) Mon camarade son fusil (le fusil de mon camarade) etc. 
Two reasons favoured this linguistic policy in the colonies; first, in the early days of colonisation, education was in the hands of Catholic missionaries who had inherited from the Roman Empire a strong tendency toward linguistic and cultural centrism. This inclination, coupled with France's strong propensity for cultural imperialism, led to schooling that was virtually entire in French and to the resulting devaluation of African languages. Around the $20^{\text {th }}$ century, missionary influence waned rapidly and the French government assumed responsibility for colonial education. Echoing earlier directives, the decree of 10 May 1924 clearly stated: "Article 64: Le français est seul en usage dans les écoles. Il est interdit aux maîtres de se servir avec leurs élèves des idiomes du pays". But beyond this prohibition was the intimidating ban imposed on the students themselves by means of the infamous system known as 'le symbole': an object which was circulated from pupil to pupil as each was caught by his mate speaking his native tongue. At the end of the day, the unlucky holder of 'le symbol' was subjected to corporal punishment by the teacher. Moreover, neologisms and ungrammatical French were severely suppressed.

\section{EDUCATIONAL POLICY AFTER THE BRAZZAVILLE CONFERENCE OF 1944}

The Brazzaville conference which focused on the relative autonomy of the colonies in relation to their economy with a possibility of self-determination by the African populations, was very conservative on what concerned the linguistic aspect (Queffelec, 1995). The ministerial Order of 22 $2^{\text {nd }}$ August 1945 stipulated that, "elementary primary education which has as its essential objective to rule and accelerate the evolution of the African populations, is done only in the French language". It was at this moment that stickers were placed on all doors in African schools with the famous, "It is forbidden to speak the dialect within the school campus". Henceforth, any pupil who was caught speaking any language other than French had to carry round their neck the famous 'symbol'.

The word 'dialect' as used on 'the symbol' was intentional. The colonisers didn't consider African languages as languages per se. African languages were considered inferior and so, could not be given the status of 'a language' as was the case with the French language.

The institution of 'the symbol' had as immediate consequence the delimitation of two distinct spaces: the school campus which was reserved for the French language and the out-of-school space reserved for the other languages. 'The symbol' was a real nightmare for the African pupil. Fredric Michelman (1995) in comparing French and British colonial language policies, states Frantz Fanon's position in Black Skin, White Masks. Fanon analyses the almost pathological response of educated West Indians vis-à-vis the French language: anything less than pure Parisian (such as the use of Creole or a West Indian accent) relegates the speaker to a less human category. In the same vein, Pauline Hountondji wrote in Présence Africaine: "The linguistic behaviour of the African, when expressing himself in French, has all the characteristics of a neurosis". He describes this neurosis obsession with the search for linguistic perfection in French as contributing to the intellectual's increasingly impoverished rapport with his native language. As a corollary to the draconian imposition of French in the schools, there was thus a simultaneous devaluation of African 'dialects' (a 'dialect' presumably being something less than a 'language'), justified in part by the spurious theory of superior and inferior languages. In these circumstances, it is not at all surprising that no encouragement was given by the French government to the transcription and use of African languages in its colonies.

The Ivorian novelist, Bernard Dadié (2003), who passed on in March 2019 at the age of 103, had this to say about the protagonist in his novel, Climbié, who was a victim of 'the symbol':

Climbié marche, la tête pleine d'idées, cherchant de se débarrasser au plus tôt de ce petit cube, si lourd parce qu'il est le symbole même de l'enseignement dispensé. Le symbole ! Vous ne savez pas ce que c'est ! Vous en avez de la chance. C'est un cauchemar ! Il empêche de rire, de vivre dans l'école, car toujours on pense à lui. On ne cherche, on ne guette que le porteur du symbole. Où est-il ? N'est-il pas chez celui-là ? Cher cet autre ? Le symbole semble être sous le pagne, dans la poche de chaque élève. L'on se regarde avec des yeux soupçonneux. Le symbole a empoisonné le milieu, vicié l'air, gelé les cœurs ! [...] A cause de ce symbole, c'était pour les élèves un vif plaisir de s'éloigner de l'école dès que la sortie était sonnée. $(115$ - 116).

'The symbol' was an inhibited factor for generations of young Africans. It was equally a handicap on the psychopedagogic plan. From the moment of the decision to use 'the symbol', the linguistic competence of the African child who got to school, was compared to that of a French child who already had some mastery of the French language. The colonisers failed to understand that the African child had to learn the language skills from scratch: reading, writing, and especially formulating his thought in French. Consequently, the African child who could neither understand nor reason in French, could only learn by mechanically reciting words and sentences that represented 
The Repossession of a Complex Language: The Case of The French Language in Cameroon

notions he didn't understand or thought of. More so, the form of the language the child learned was mainly the written form and especially the descriptive aspects of literary texts. This pedagogical practice gave birth to a variety of the French language in Cameroon known as 'français académique' or 'français des scolarisés' which later became the variety used by the educated class.

Fredric Michelman (ibid.) opines that although the assimilationist principle of making of all Africans French cultural clones persisted as an ideal throughout the colonial period, in practice it was only seriously applied in education after World War II. During the first half of the $20^{\text {th }}$ century, this approach was modified by the principle of 'adaptation' whereby a very limited number of African children were exposed to a simplified curriculum designed to train a small cadre of loyal, mainly low-level subordinates to assist the colonial administration. Very few were able to obtain more standard university-level degrees and it is from their ranks and from those of the immediate postWorld War II University graduating classes that most of the contemporary francophone writers emerged.

\section{THE FRENCH LANGUAGE IN POST-INDEPENDENT CAMEROON}

French Cameroon got its independence on $1^{\text {st }}$ January 1960 and united with the British Southern Cameroon on $1^{\text {st }}$ October 1961 to form the Federal Republic of Cameroon. The constitution of the young state, in its article 1 (3) proclaimed French and English as the official languages. The new authorities, who took control after the colonialists, assigned two functions to the languages: the consolidation of national unity and integration, and the development of the country with opening to the rest of the world. The first president of the country, Amadou Ahidjo had love for French culture and the French language. To him, the language was politically useful. This was equally the case with other francophone presidents like Omar Bongo of Gabon and Félix Houphouet-Boigny of Côte d'Ivoire. Talking of the latter, Bouin (ibid. p.46) writes:

Son raisonnement comme son style sont africains, avec une constant à la situation de l'énonciation, et l'on admire, dans ses discours, non les belles tournures et les mots rares, car ils sont absents, mais la manier africaine d'utiliser la langue, par ailleurs exemple de fautes et d'écarts.

Like President Houphouet and many other presidents of newly independent French African countries, President Ahidjo's French language was void of literary, poetic and spiritual aspects of French culture. Even if he wasn't a partisan of the teaching of home languages in schools, we nevertheless, do not find degrading judgement of this in his speech. Ahidjo gave the French language an essentially practical role. It may not be an exaggeration to say that this importance given to the language by Ahidjo (and all other Francophone Cameroonians of the political class), influenced the attitude of other Francophone Cameroonians vis-à-vis the French language. What is certain is that, to speak the 'French of France' in countries like Côte d'Ivoire and Cameroon has never known the same enthusiasm as in some Francophone African countries like Senegal, Gabon or Congo Brazzaville (Kouadio N'Guessan, 2008).

During independence, Cameroon was linguistically characterised by a situation of diglossia, a situation which still prevails today: diglossia between the French language, which Lafage (2003) calls 'the upper variety' used in the administration, in schools, by the judiciary, etc. and underestimated home languages assimilated to 'the lower variety' (used within family circles, in markets, in daily activities, etc.), diglossia between the 'French of the elite' closer to the norms of the coloniser, and 'Pidgin French', a pidginised variety spoken by a growing urban majority with less or no education.

Independence brought with it the democratisation of education with the creation of schools, colleges, vocational institutions and the Federal University of Cameroon in 1962. Between 1960 and 2016, the growth rate in the 'Francophone' population has been tremendous. It went from $1.9 \%$ to $2.7 \%$ in 2016 . In spite of this growth, the success rate in schools dropped in primary and secondary schools. While the use of the French language was increasing, its quality was dropping. Its acquisition was not exclusively done only in schools, which were losing their prestige and quality. Massive rural exodus by young Cameroonians in search of better livelihood, brought about intermingling in the major cities which favoured the spread of the local variety of the French language in a country with no dominant home language.

Today, all social classes are influenced by the French language. Public servants like intellectuals communicate in the language. Labourers, market dwellers, etc. who form the majority of the urban proletariat are obliged to communicate among themselves and with their employers in a language they do not very well master. This is equally the case with dropouts and street children who, in their daily interaction, use the French language. Depending on 
the mode of acquisition or appropriation of the language, the length of exposure of the learner to the standard form, there are three varieties of the language which correspond to three social strata.

\section{VARIETIES OF THE FRENCH LANGUAGE IN CAMEROON}

The French language spoken in Cameroon has always been considered a continuum comprising of diverse varieties made up of the basilectal (remote variety), the mesolectal (creole continuum) and the acrolectal (standard variety). Even if the use of the language has reduced the barrier between the different varieties, it could, for sociolinguistic analysis, still be classified under two main varieties: Cameroon popular French (the social variety), and the jargon of youths.

The French language in Cameroon can today be considered a vehicular language. Mendo Zé (1992) states that Cameroon home languages play an important role in the variety of the French language used by Cameroonians. These languages influence communication among Cameroonians and their linguistic behaviours. From an internal point of view, the French language in Cameroon has developed linguistic varieties which identify its speakers. We thus have what can be termed regional Cameroon French depending on a number of factors.

\subsection{CAMEROON POPULAR FRENCH (CPF) OR THE SOCIAL VARIETY}

Cameroon popular French was born out of the 'petit nègre' earlier mentioned in our study. It started in the capital city, Yaoundé and gradually spread to other parts of the country in the early years after independence. Early researchers like Mendo Zé (1992), Biloa (2003), Wamba and Noumsi (2003) who worked in this domain, arrived at the conclusion that the variety is in progress. Joachim Oelsner (2000) in his introduction in Le tour du Cameroun, writes that the phonology of Cameroonian home languages interfere with three colonial languages that have existed in the country, that is, English, French and German. He holds that, "La transcription de tout ce que l'on pourrait appeler les réalités africaines comme les noms des villes et villages, les ethnies et tribus avec leurs langues ou leurs rites, mais leurs noms de personne [...] n'est pas homogène et donne souvent l'impression d'un babel linguistique. Ainsi, pour le même nom existent toujours plusieurs versions. Quelques exemples pour les noms de personnes: Folefa, Folifack, ou Fouelefack; Tsafac, Tchafack, Tsofack; Ondoua, Ondua, Ondou, etc. Wamba et al. (2003) think that when a foreign language (in this case, the French language) imposes itself as a second language to one or more home languages, the second language is enriched by borrowing. In this light, the onomastic (in general) or the anthroponomy will constitute lexical or terminological interference, giving that names of persons function in the second language as borrowings from the source language. Queffelec (1998:358) observes that such borrowings are generally graphics (graphic of the item in the source language and the system of the transcription of the second language). Such hybridity is at the origin of the plethora of varieties in the orthography of these borrowings. The multiplicity of orthography is sometimes at the origin of errors and can create linguistic insecurity for the L2 user who does not master the L1 code and equally does not know which reading system should be adopted.

These observations find their pertinence in the existence, in Cameroon popular French, of the different forms in orthography and articulations of borrowed terms such as: Fo/Fo'o; Essingan/Essigang; Laakam/Lakam.

Wamba et al. (ibid) say that, in like manner, the language of advertisement in Cameroon is linguistically and sociolinguistically diverse. The language contains other aspects of linguistic variation, especially through the phenomenon of borrowing. As B. Tsofack (2002) observes:

The semiology of borrowing in advertisement in Cameroon reveals two types of situations: the search for the right word to fill the lexical and cultural gap, and the lexical creation itself. In the latter case, the borrowings are seen as interferences from the linguistic system of the mother-tongue.

The fact that this social variety is in constant progress simply means that it is not a creole but a variety in the marking which is used till date by both educated and less educated Cameroonians. The following examples demonstrate the characteristics of the variety:

On the morpho-syntactic plan, we have the following examples:

1) Determinants are most often dropped.

- Tu vas prendre bus? (Tu vas prendre le bus?)

- On peut prendre boisson? (Pouvons-nous prendre une boisson?)

- Tu veux ballon? (Veux-tu un ballon?) 
2) A peculiar way of using personal pronouns

- Il les a donné des places (Il leur a donné des places)

- La pluie n'a pas laissé leur (La pluie ne les a pas épargnés)

- On va tuer lui (On va le tuer)

3) The omission of some linking morphemes like prepositions

- J'ai jamais été école (Je n'ai jamais été à l'école)

- Je parti Yaoundé (Je vais à Yaoundé)

\subsection{THE HYBRID VARIETY (CAMFRANGLAIS)}

Camfranglais, which is a fusion of Cameroonian languages, French and English, is a jargon which came into existence from the early 1980s and used by youths. The reasons for the creation of this are the same as those that have given rise to other similar jargons, that is: wilful coded language, renaissance, group identification, etc. Camfranglais is characterised at the lexical level by semantic changes and borrowings from the local languages. Thus, words from home languages are retained (example: nkap 'money' from the Bamileke, 'mola' from the Bakweri, ' $a$ mot' from Beti/fang, etc.), modified, truncated and at times associated to elements of other languages (example: 'Mola, je te hia mo' friend, I like your way of doing things). At times, words are derived or composed with different metaphorical or metonymical meanings. We can cite the following:

At the morpho-syntactic level:

1) The introduction of new invariable verb forms borrowed from English and the home languages. 'Je te hia mo' (I like your ways).

2) The non-respect of number and gender. At times, gender is not defined: 'ma ngo or mon ngo', (ma petite amie).

The following examples illustrate the use of this variety by youths in their daily interactions:

Jean de Dieu Momo passe sur l'arène et il sabote Benjo Zébazé après ça le kick boxing a biging entre eux, après ça c'était Cabral Libih qui était invité dans la grande interview, après son passage mollah son fan club voulait tuer kelkun avec le boucan. Après il voulait go take général.

- Jean de Dieu Momo était l'invité à l'émission, l'Arène où il s'est attaqué à Benjo Zebazé avant qu'une bagarre n'éclate entre eux. Après le passage de Cabral Libih à l'émission, Grande Interview, ses fans se sont réjouirent de son passage. Après quoi, il est allé emprunter le car de l'agence « Général Express».

- On a seloman compris le feu à Bafoussam chez son agence, les gars étaient content juska. Il y'a eu incendie à l'agence de Bafoussam, ce qui a fait réjouirent les gens.

- Il y'a un gars ki a montré un meeting de Joshua au nord. Un garçon a montré les images du meeting du candidat Joshua Osih tenu dans la région du nord.

- Oui, Joshua est go faire sa tournée là-bas au nord comme Kamto, un perika a filmé ça il nous a send, moi en moins de 15min, les gars ont lap plus de 200 fois.

Comme le candidat Kamto, Joshua Osih a éffectué une tournée dans la région du nord qui a été filmé par un jeune qui nous a envoyé les images, ce qui a fait réagir plus de 200 personnes.

- Vrai vrai la comparaison entre lui et Kamto fesait lap comme il avait d'abord nack sa poitrine ke na yi be leader for opposition for dis pays.

La comparaison entre lui et Kamto est intéressante étant donné qu'il se considère le leader de l'opposition.

- Eh !j'allais oublier Garga Haman ki a chassé Cathy Toulou du plateau. Il a dit hoha kel n'est pas une invitée comme lui kel sort sinon il sort en solo.

Eh ! J'allais oublier Garga Haman qui a fait partir Cathy Toulou du plateau. Il a dit qu'elle n'était pas une invitée et que si elle ne sortait par, lui (Garga) devait s'en aller.

- Maintenant Bertold nous a démontré ke Fobassou la ke l'armée a arrêté était die depuis comme le mbom ki avait aussi win l'eman sans write là.

Bertold nous a démontré que Fobassou qui a été arrêté par l'armée était bien longtemps décédé, comme c'était le cas avec le candidat qui avait était déclaré admis à l’Enam sans n'avoir présenté le concours. 
- Le MRC a zappe les gars sur son alliance avec l'opposition et insiste ke c'est lui ki doit tirer le penalty du $7 / 10 / 2018$.

Le MRC a déjoué les gens en ce qui concerne la formation d'une alliance avec les autres partis de l'opposition et insiste que ce son candidat qui devrait se présenter à la présidentielle.

- La suite va se poursuivre dans les différents débats du dimanche canal presse, vision 4, STV, équinoxe, j'oublie koi?

La suite va se poursuivre dans les différents débats du dimanche, canal presse, vison 4, STV, équinoxe et j'en passe.

The use of this variety by youths can be seen as a sort of linguistic revolution, an identification of the 'self'. The variety differentiates its users from 'elitist French' users, the French of the high society. With the passing of time, the main groups that voluntarily used a 'high variety' of the French language to 'show-off and to demarcate themselves from the rest of the society' are now limited. Today, there is a rapprochement between the mesolectal and the acrolectal varieties, and an assimilation of some traits of the basilectal variety. There is thus some sort of an indigenous form of the language in Cameroon which turns to be uniformalised.

\subsection{THE USE OF SHORT MESSAGE SERVICE (SMS)}

Another specificity of the hybrid variety is the manner in which younger Cameroonians communicate with the use of short message service (SMS). In a study entitled, 'les SMS tuent la langue française', Mawel Arnaud (2018) concludes thus:

La langue française a mal. Elle est victime du mauvais usage qui menace de lui 'tordre le cou'. Les personnes qui l'emploient pour communiquer par Short Message Service (SMS) sont à l'origine de sa souffrance. Elles se sont résolues à lui amputer ce qu'elle a d'essentiel pour échanger rapidement par écrit et à moindre coût.

This infection of the French language in Cameroon is the result of aspects such as mode, the offhand manner of the writer, economy of airtime, the encoding of messages, the mixture of the French language with the English language and other home languages, etc. If the elderly class of Cameroonians wrote the French language with seriousness and rigour, today the younger generation takes lightly the use of the language, especially in writing SMS, a communication means brought about with the advent of ICTs and other electronic means of communication.

Most often, 18 year old Stéphane Nkot uses SMS. When interviewed, he had this to say, "j'utilise plus les SMS que les appels ou les réseaux sociaux pour communiquer. Chaque mois, j'active un forfait des SMS pour une durée de 30 jours et dès lors, j'écris sans cesse". With the use of this atypical style of writing, youths are those who do more harm to the language. They completely ignore the rules of grammar, orthography, morphology and syntax. Grammatical agreement does not exist, while the orthography of words has changed. Words and expressions, even the shortest ones, are abbreviated or transformed into alphanumerical codes. We can cite the following examples:

Maa c mw ki tè call (Maman c'est moi qui t'appelle)

- 7 bel fi è genti g laim (Cette belle fille est gentille, je l'aime)

- Salut, sa va bien? (Salut, est-ce que ça va ?)

- On ce conne pas vremt. (On ne se connait pas vraiment)

- Jaimere faire conaisance avec toi. (J'aimerais faire ta connaissance)

- On est otografiquem't pas compatible. (Nous ne sommes pas amis)

Writing in this manner, the number of words are reduced, as well as the number of pages of a message. The writer looks at the immediate gain. Stéphane holds that, "pour quelqu'un qui paie la page du SMS à 50 FCFA, il fait des économies".

Unfortunately, the practice has negative effects. It affects the writing of pupils and students in schools. Their essays are full of both grammatical and orthographic errors. It equally affects their vocabulary. For Berthe Ngo Moga, a French language teacher:

C'est un sacrilège; malgré notre dévouement au travail, les SMS diluent les connaissances des élèves. Ils ne respectent aucune règle. Lorsqu' on les lit, on a l'impression qu'ils ont créé une autre langue intermédiaire à la langue française.

These consequences are equally noticed in the speech of pupils and students. Whether spoken or written, the French language has lost its essence, especially with the suppression of dictation at the secondary level for the past 
The Repossession of a Complex Language: The Case of The French Language in Cameroon

ten years and the introduction of other codes like Spanish, German, Mandarine and home languages into the curriculum.

In 1983, Susanne Lafage carried out a similar study in Côte d'Ivoire and found out that $65.67 \%$ of Ivorian university students were favourable to the use of what they consider as Ivorian popular French (français populaire ivorien, FPI) which is the equivalence of Cameroon Popular French (CPF). This tendency cuts across most, if not, all black French African countries. According to the target samples in Lafage's study, FPI is preferred by most Ivoirians because the variety does not only bridge social barriers, it equally enables greater comprehension among multiethnic and multilingual populations. One of the students in Lafage's study opines:

C'est le français du peuple. C'est celui qui réellement nous identifie et brise les barrières tribales et les particularismes. Ce français met le ministre au niveau du manœuvre et tout le monde le comprend sans même l'apprendre.

But when one considers the question of the emergence of an indigenous variety of the French language, and especially that of its valorisation, opinions differ. Most Cameroonians think that there is an indigenous variety which has led to terms such as 'le français camerounais' which is different from 'le français gabonais', 'le français tchadien' or 'le français ivorien'. Boutin (2002: 108) reports the frustration of what a teacher calls, 'le manque de liberté dans l'espace francophone'. The latter states, "il faut accepter que la langue se tropicalise [...], la langue est un être vivant". This tropicalisation of the French language has created a contrast between le français camerounais' and what can be considered as purely academic French, as this other teacher interviewed by Boutin (2002) writes, "Il y a un français [....] qui n'est peut-être pas encore entériné par les normes académiques et universitaires mais qui permet aux gens de communiquer, et c'est ça le plus important".

According to another French language teacher, what is known as 'le français camerounais', has its grammatical rules which might not have been formalised but which has a structure and its logic: if this logic is not respected, then one is not speaking 'the French'.

\section{CONCLUSION}

From our analysis, it is clear that there is a variety of the French language in Cameroon which functions according to its proper norms. Because of conflict of generations, when it comes to standard of this indigenous variety, opinions differ. Most of those against what can be considered a 'new type of French language' in Cameroon are the elderly generations and the educated class; mostly teachers who were trained shortly after independence. To them, standardising Cameroon French will mean taking the risk of not being understood by other French language users. This argument is rejected by partisans of 'Cameroon French', amongst them young teachers and students. Like in Côte d'Ivoire, this class bases its argument on the attitude of the youth vis-à-vis some of their textbooks. They prefer textbooks written in a variety of language which is familiar to them. They complain of the gap that is gradually developing between the French taught in schools (le français des livres) and that which is common amongst the people (le français courant). There are teachers who do not find any inconvenience that expressions typical of 'français camerounais' be used by students on condition that, the expressions "are inserted within an acceptable syntax". The famous Ivorian writer, Amadou Kourouma, one of the apostles of Africanising and adapting the colonial language, thinks that:

Les africains ayant adopté le français, doivent maintenant l'adapter et le changer pour s'y retrouver à l'aise ; ils y introduisent des mots, des expressions, une syntaxe, un rythme nouveaux. Quand on a des habits, on s'essaie toujours à les coudre pour qu'ils moulent bien, c'est ce que vont faire et font déjà les Africains du français (qtd. in Kouadio 2005: 177).

Without being original, the French language in Cameroon has some exemplary specificities. At the beginning it was a colonial-imperialist language, thus a language of the oppressor. With time, and with socio-political realities, it became a vehicular language shared by Cameroonians. Many factors were in favour of this change: the absence of a common language used by Cameroonians at the eve of independence permitted the infiltration of the French language into the habits of the social groups that were in contact with Europeans: labourers, house-maids, soldiers, employees, neo-Christians, etc. Pre and post-colonial schools helped the spread of the language which today is used, without any complex, by many Cameroonians, though they use varieties that are more or less far-off from the 'main stream' French. Henceforth, the French language should be considered a Cameroonian language. 


\section{SOURCES OF FUNDING}

None.

\section{CONFLICT OF INTEREST}

None.

\section{ACKNOWLEDGMENT}

None.

\section{REFERENCES}

[1] Alexandre, Pierre, Langues et Langage en Afrique Noire. Paris: Payot, 1967.

[2] Boutin, A. Béatrice, Description de la variation: Études transformationnelles de phrases du français de Côte d'Ivoire. Thèse de doctorat, université Stendhal-Grenoble 3. 2002

[3] Boutin, A. Béatrice, «La variation dans la construction verbale en français de Côte d’Ivoire », Revue québécoise de Linguistique, vol. 32, n 2, Montréal, RQL (UQAM), 2003, 15-45.

[4] Dadié, Bernard. B. Climbié, Abidjan, Nouvelles Éditions Ivoiriennes, 2003.

[5] Delafosse, M. Vocabulaires comparatifs de plus de 60 langues ou dialectes parlés à la Côte d'Ivoire et dans les régions limitrophes, Paris, Ernest Leroux, 1904.

[6] Ekanza, S. P. Colonisation et sociétés traditionnelles. Un quart de siècle de dégradation du monde traditionnel ivoirien: 1893-1920. Thèse de 3e cycle, Aix-en-Provence, 1972.

[7] Edmond Biloa, «L'influence du français sur l'anglais camerounais». Sudlangues, 2, http://www.refer.sn/Sudlabgues, 2003.

[8] Edmond Biloa, «Structure phrastique du camfranglais» in G. Echu et A.W. Grundstrom (eds). Bilinguisme officiel et communication linguistique au Cameroun, New York, 1999.

[9] Edmond Biloa et Paul Fonkoua, «Imaginaire linguistiques ou représentations du Français et des langues identitaires autochtones au Cameroun». Sudlangues: Revue électronique internationale du langage, 2, http://www.refer.sn/Sudlangues, 2010.

[10] Ethnologue 15th Edition: SIL International. Chalmers University of Technology. 2005.

[11] Gadet François, Le français populaire. Paris, PUF, Que sais-je ?1992.

[12] George, Echu, «Le camfranglais : l'aventure de l'anglais en contexte multilingue camerounais» in Ecritures VII : L'aventure. Yaoundé éd. CLE, 2001, 207-221.

[13] Gordon, David. The French Language and National Identity 1930-1975. The Hague: Mouton, 1978.

[14] Kouadio, N. Jérémie, L'enseignement du français en milieu baoulé. Problèmes des interférences linguistiques et socioculturelles. Thèse de $3^{\mathrm{e}}$ cycle, université de Grenoble 3, 1977.

[15] Kouadio, N. Jérémie, "Le nouchi et les rapports dioula-français », in Des inventaires lexicaux du français en Afrique à la sociologie urbaine. Hommage à Suzanne Lafage. Revue Le français en Afrique Noire, $\mathrm{n}^{\circ} 19$, DidierÉrudition, 2005, 177-191.

[16] Lafage, Suzanne, « Le lexique français de Côte d'Ivoire. Appropriation et créativité », vol. 1, in Revue du Réseau des observatoires du Français contemporain en Afrique, $n^{\circ} 16$, Institut de Linguistique française, CNRS UMR 6039-Nice, 2002.

[17] Lockwood, Allison. « Legislating language: Will it Work? » The Wall Street Journal 13 Mar. 1973: 22.

[18] Mawel Arnaud Nicolas, "Le SMS tue la langue française" in Repère $\mathrm{N}^{\circ} 670$ lundi 3 septembre 2018.

[19] Mendo Zé, Gervais, Une crise dans les crises: Le français en Afrique noire; le cas du Cameroun, Paris, ABC, 2003.

[20] Oelsner, Joachim, Le Tour du Cameroun. A travers des mémoires et thèses de la Faculté des Arts, Lettres et Sciences Humaines de l'Université de Yaoundé I, Paris, L'Harmattan, 2000. 
[21] Ouguéné Essono, La presse écrite dans la dynamique du français au Cameroun: essai d'analyse de l'information écrite et produite dans les journaux camerounais. HDR en science de l'information. Université M. de Montaigne, Bordeaux 3, 2011.

[22] Queffelec, Ambroise, « Le français en Afrique Noire », in Gérald Antoine et Robert Martin (éd.), Histoire de la langue française : 1914-1945, Paris, Éditions du CNRS, 1995, 823-860.

[23] Rivarol, Antoine, « Discours sur l'universalité de la langue française », 1784.

[24] Tsofack, Benoit, «Publicité, langue et plurivocalité au Cameroun ». Sudlangues, 1, 2002, 22 - 36.

[25] Wamba, R. \& Noumssi, G. «Le français au Cameroun contemporaine : statuts pratique et problèmes sociolinguistiques ». Sudlangues: Revue électronique internationale du langage 2. 2003, 1-20. 